\title{
ESTIMATION OF REBURNING POTENTIAL OF SYNGAS FROM SEWAGE SLUDGE GASIFICATION PROCESS
}

\author{
Sebastian Werle \\ The Silesian University of Technology, Institute of Thermal Technology, ul. Konarskiego 22, \\ 44-100 Gliwice, Poland
}

\begin{abstract}
The motivation of this work was to define the reburning potential of sewage sludge gasification gas (syngas). Numerical simulation of co-combustion process of syngas in hard coal-fired boiler has been done. All the calculations were performed using the Chemkin program. Plug-Flow Reactor model was used. The calculations were modelled using GRI-Mech 2.11 mechanism. The highest NO conversions are obtained at the temperature of about 1000-1200 K. The highest reduction efficiency was achieved for the molar flow ratio of syngas equal to $15 \%$. The combustion of hard coal with sewage sludge - derived syngas reduces NO emissions and the amount of coal needed to produce electricity and heat. Advanced reburning, which is a more complicated process gives efficiency of up to $80 \%$. The calculations show that the analyzed syngas can yield better results.
\end{abstract}

Keywords: gasification, sewage sludge, plug flow reactor

\section{INTRODUCTION}

According to Polish Regulations, sewage sludge belongs to group No. 19, including waste from treatment installations and the equipment for waste management, waste water treatment plants and from the treatment of drinking water and water for industrial purposes. According to the Polish Ecological Policy and the objectives of the National Waste Management Plan 2014 (NWMP) and the National Urban Wastewater Treatment Program (NUWTP), the quantity of sewage treated in Poland systematically increases. In 2010 in Poland, 612.8 thousand tons (dry basis - d.b.) of sewage sludge was produced. Moreover, it is estimated that the quantity of sludge which will be produced in Poland in 2018 will be equal to 706.6 thousand tons (d.b.).

Currently, the predominant method for the disposal of sewage sludge in Poland is its storage and agricultural application (Werle and Wilk, 2010). This is highly unfavorable. The main problems are a the high percentage of stored sewage sludge and a lack of installations for its thermal utilisation. Thermal processes can be used for the conversion of large quantities of sewage sludge (e.g., in large urban areas) into useful energy. Processes for thermal utilisation of sludge can be developed at existing installations (e.g., heating plants, power plants, or cement plants) or in newly built facilities.

There is a large and pressing need for the development of thermal methods for the disposal of sludge. It is worth emphasising that effective from January 1,2013, the storage of sewage sludge with parameters as presented in Table 1 will be banned in Poland.

Gasification is one of the possible ways of sewage sludge utilisation. This process provides an attractive alternative for the treatment of sewage sludge. It has several advantages over traditional

*Corresponding author, e-mail: Sebastian.werle@polsl.pl 
combustion. It takes place in a low oxygen environment and limits the formation of dioxins and large quantities of $\mathrm{SO}_{\mathrm{x}}$ and $\mathrm{NO}_{\mathrm{x}}$. Furthermore, it requires just a fraction of the stoichiometric amount of oxygen necessary for combustion. As a result, the volume of process gas is low, requiring smaller and less expensive gas cleaning equipment. A lower gas volume also means a higher partial pressure of contaminants in the off-gas, which favours more complete adsorption and particulate capture. Finally, gasification generates a fuel gas that can be integrated with e.g. combined cycle turbines or engines.

Table 1. Polish criteria for the storage of sewage sludge in a non-hazardous waste landfill

\begin{tabular}{|c|c|c|}
\hline & Parameter & Value limit \\
\hline 1 & 2 & 3 \\
\hline 1 & Overall organic carbon (OOC), \% d.b. & 5.0 \\
\hline 2 & Loss at calcinations (LOC), \% d.b. & 8.0 \\
\hline 3 & The higher heating value, MJ/kg d.b. & Maximum 6.0 \\
\hline
\end{tabular}

Syngas is increasingly seen as a source of environmentally clean fuels and has potential to become a major fuel in the production of essentially pollution - free energy. There are many advantages of using syngas as a fuel: it is inexpensive and can be used for clean combustion resulting in a significant reduction in pollutant emissions. Syngas can be also be employed as a supplemental fuel do reduce the consumption of other fuels, such as pulverised coal and fuel oil. In addition to this, it has potential as a reburning fuel to reduce $\mathrm{NO}_{\mathrm{x}}$ emission. Polish energy sector offers a great potential of utilising the gas and simultaneously reducing $\mathrm{NO}_{\mathrm{x}}$ emissions.

\section{REBURNING}

Nitrogen oxides, also known as $\mathrm{NO}_{\mathrm{x}}$, are important and problematic contaminants produced in combustion processes (Dąbrowski and Piecuch, 2011; Piecuch et al., 2009; Szkarowski, 2001; Szkarowski, 2002). The nitrogen chemistry in combustion processes is summarised in Fig. 1.

$\mathrm{NO}_{\mathrm{x}}$ are formed along three routes: thermal and prompt formation from $\mathrm{N}_{2}$ and oxidation of fuel-bound nitrogen. Thermal $\mathrm{NO}$ evolves from the recombination of $\mathrm{N}_{2}$ and $\mathrm{O}_{2}$, described by the extended Zeldovivch mechanism (Norman et al., 2009):

$$
\begin{aligned}
\mathrm{N}_{2}+\mathrm{O}_{2} & \leftrightarrow \mathrm{NO}+\mathrm{N} \\
\mathrm{N}+\mathrm{O}_{2} & \leftrightarrow \mathrm{NO}+\mathrm{O} \\
\mathrm{N}+\mathrm{OH} & \leftrightarrow \mathrm{NO}+\mathrm{H}
\end{aligned}
$$

Reaction (1) has high activation energy, which controls the reaction rate of thermal- $\mathrm{NO}_{\mathrm{x}}$ formation; temperatures above $1400{ }^{\circ} \mathrm{C}$ are required for the reaction to occur. The Zeldovivch mechanism is reversible and reduces $\mathrm{NO}$ when the equilibrium concentration of $\mathrm{NO}$ is low enough, given that the temperature is sufficiently high for the Zeldovivch mechanism to be active. Prompt NO (Norman et al., 2009 ) is initiated by the reaction between $\mathrm{N}_{2}$ and hydrocarbon radicals forming a volatile- $\mathrm{N}$ (an intermediate gaseous compound) species, which is oxidised to $\mathrm{NO}$ or reduced back to $\mathrm{N}_{2}$. Prompt $\mathrm{NO}$ is of minor importance and occurs predominantly under fuel-rich conditions. The conversion of fuelbound nitrogen contributes to most NO formed during combustion of coal. Fuel-N is split into a volatile- and char- $\mathrm{N}$ during the devolatilisation. The volatile- $\mathrm{N}$ transforms into either $\mathrm{NO}$ or $\mathrm{N}_{2}$, while char- $\mathrm{N}$ reacts through a set of heterogeneous reactions along with the oxidation of char. The split between volatile- and char-N varies with a type of coal and depends on qualities such as nitrogen 
content, coal rank and volatility, but is also depends on combustion conditions, such as heating rate and temperature. $\mathrm{NO}$ formed can also be reduced to $\mathrm{N}_{2}$. Similar to the prompt formation, $\mathrm{NO}$ can be reduced by hydrocarbons to volatile-N under fuel-rich conditions which is known as reburning.

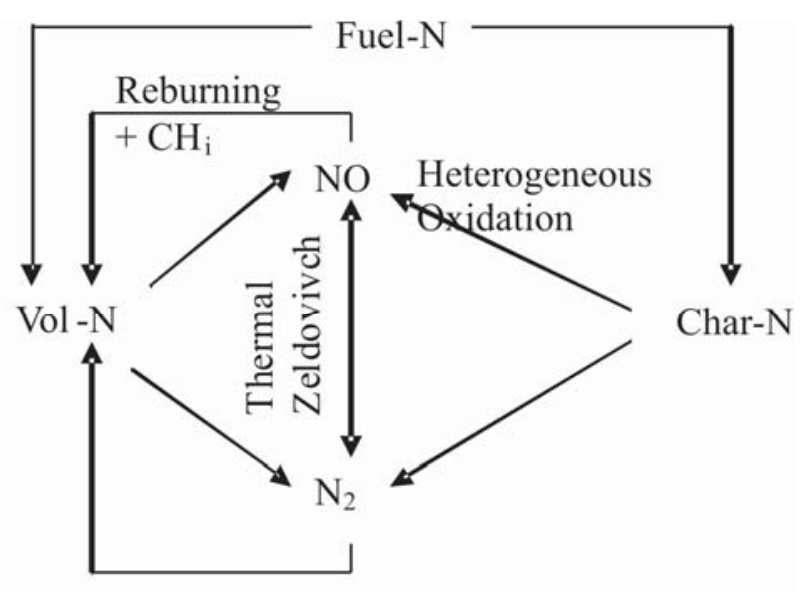

Fig. 1. Overall mechanism of NO formation and reduction

Nowadays, reburning is shown as one of the most efficient and attractive techniques that can be applied to reduce $\mathrm{NO}_{\mathrm{x}}$. In this technique, after the primary combustion zone, a secondary fuel is injected into the boiler in the so-called reburn zone, thereby establishing fuel-rich conditions. The reburn fuel produces hydrocarbon radicals, which can interact with $\mathrm{NO}$ and therefore reduce the final $\mathrm{NO}_{\mathrm{x}}$ emissions. To complete the process, post combustion air is injected in order to eliminate unburned hydrocarbons.

In the past several years, reburning has been extensively studied. The first researchers who developed this concept calling it 'reburning' were Wendt, Sterling and Matovich (1972). They suggested an injection of additional fuel along the main flame, so that the emission of $\mathrm{NO}_{\mathrm{x}}$ might by minimised by forming a reductive atmosphere. Reburning was first demonstrated as a practical $\mathrm{NO}_{\mathrm{x}}$ reduction method in Japan where the concept of reburning was first applied to a full-scale boiler (Takahashi et al., 1983). Because of this successful example and high efficiency of reburning technology leading to a of $\mathrm{NO}_{\mathrm{x}}$ emission (more than 50\%), many investigators have conducted bench-scale and pilot-scale reburning tests. Laboratory (Folsom et al., 1991) and the first commercial (Folsom, 1997a) boilers showed that the $\mathrm{NO}_{\mathrm{x}}$ emission may be reduced by up to $60 \%$. It has also been reported (Smoot, 1998) that many European countries conduct reburning projects in coal fired boilers with a goal of less than $200 \mathrm{mg} / \mathrm{m}^{3}{ }_{n}$ $\mathrm{NO}_{\mathrm{x}}$ emissions. Four demonstration projects in the Department of Energy's Clean Coal technology Program are being carried out in the US. One of these uses coal as the reburning fuel, while the others use natural gas. $\mathrm{NO}_{\mathrm{x}}$ reductions varied from $30 \%$ to over $70 \%$, depending on the boiler type and scale, reburning fuel and simultaneous use of low- $\mathrm{NO}_{\mathrm{x}}$ burners. In the US its principal application has been to coal-fired boilers, while in Europe and Japan reburning applications include coal, oil and gas-fired boilers as well as municipal solid waste (MSW) incinerators. The European example of gas reburning is a $600 \mathrm{MW}$ coal-fired boiler at Longannet (Lanigan et al., 1991). This is the largest application of gas reburning in Europe. As far as the kind of the reburning fuels is concerned, they should be volatile and highly reactive. Such fuels are natural gas (Adams and Harding, 1998), coke-oven gas (Smoot et al., 1998), synthesis gases (Frassoldati et al., 2007) and light fuel oils. It should be fuels which while decomposing in the reduction zone produce a large amount of $\mathrm{CH}_{\mathrm{i}}$ radicals. The results of recent investigations have shown that also heavy fuel oil, lignite (Hardy, 2003), some kind of biomass (Adams and Harding, 1998; Cariln et al., 2009) and even some municipal waste (Maly, 1999) may be good reburning fuels. A good example of reburning fuels can be the gas obtained from sewage sludge gasification. 
The chemistry of reburning is very complex and involves a large number of reactions of formation and consumption of many different species. NO reduction through reburning usually includes interactions of hydrogen cyanide $(\mathrm{HCN})$, ammonia $\left(\mathrm{NH}_{3}\right)$ and NO species (Shen et al., 2004)]. These species react in a series of reactions, but finally they end up as NH and N, as shown in Fig. 2.

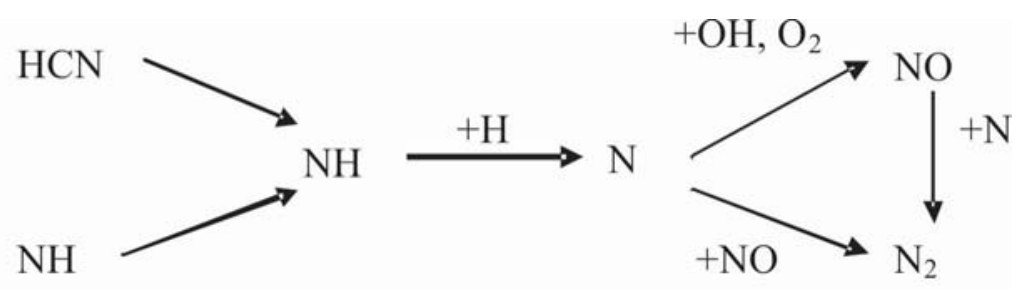

Fig. 2. Reaction-path diagram illustrating step in volatile-N conversion to $\mathrm{NO}$ or $\mathrm{N}_{2}$

Under fuel-rich conditions, the formation of $\mathrm{HCN}$ relies strongly on the concentration of hydrocarbon species:

$$
\mathrm{CH}_{\mathrm{i}}+\mathrm{NO} \rightarrow \mathrm{HCN}+\ldots
$$

which then decays through $\mathrm{NCO} \rightarrow \mathrm{NH} \rightarrow \mathrm{N}$, as shown in Eqs. (5-8), and ultimately reaches $\mathrm{N}_{2}$ via reverse Zeldovich reaction (Eq. 8):

$$
\begin{gathered}
\mathrm{HCN}+\mathrm{O} \rightarrow \mathrm{NCO}+\mathrm{H} \\
\mathrm{NCO}+\mathrm{H} \rightarrow \mathrm{NH}+\mathrm{CO} \\
\mathrm{NH}+\mathrm{H} \rightarrow \mathrm{N}+\mathrm{H}_{2} \\
\mathrm{~N}+\mathrm{NO} \rightarrow \mathrm{N}_{2}+\mathrm{O}
\end{gathered}
$$

Several kinetics models have been reported to describe the reburning process with different levels of details and predictions (Bilbao et al., 1995; Dagaut et al., 1998; Galborg et al., 1998; Klipinen et al., 1992; Miller and Bowman, 1998; Smith et al., 1998;), providing an overall understanding of the interaction among hydrocarbon and nitrogen species.

Depending on their complexity and description level, these models may be classified as detailed, skeletal and reduced models. Both detailed and skeletal mechanisms are shown to be essential since they are the starting point for the development of reduced mechanism, which can be used in modelling reburning with detailed fluid dynamics, for example, in the presence of turbulent flows. The first reduced mechanism for the reburning process was developed by Glarborg et al. (1992a). This contained a four-step mechanism for methane oxidation plus two rate-of-production terms for HCN and NO. In 1996, Hewson and Bollig (1992) proposed a reduced mechanism, based on a detailed mechanism developed in the same research group that consists of 11 global reactions. Several reduced mechanism have been proposed for the GRI-Mech. Reduced mechanisms have important limitations since their predictions are accurate only for a narrow range of operating conditions. The detailed mechanism GRIMech 2.11, that consists of 279 reactions of 48 reactive species, was developed for a wide range of operating conditions.

Numerical simulation of co-combustion process of gas from sewage sludge gasification in coal-fired boiler was the aim of this work. All calculations were performed using Chemkin, the plug flow reactor model were used. Reburning potential of syngas has been defined. The influence of the reaction between reburning fuel and flue gases from coal combustion on reduction of $\mathrm{NO}_{\mathrm{x}}$ emission has been examined. The results show a relationship between relative amounts of nitric oxide on the temperature $\mathrm{T}$, the air excess ratio $\lambda$ and the reaction time $\tau$. 


\section{CALCULATIONS}

In the calculations, two gases from sewage sludge gasification process (ss1 and ss2) were used as the reburning fuel. The molar composition of the reburning fuels is presented in Table 2. Syngases composition was achieved using a non-stoichiometric approach equilibrium model calculation. This model is based on minimising the Gibbs free energy in the system (Werle, 2011; Werle, 2012).

Table 2. Molar composition of the analysed sewage sludge

\begin{tabular}{|c|c|c|}
\hline \multirow{2}{*}{$\begin{array}{c}\text { Compound } \\
\text { vol.\% }\end{array}$} & \multicolumn{2}{|c|}{ Reburning fuels } \\
\cline { 2 - 3 } & Syngas1 (ss1) & Syngas2 (ss2) \\
\hline $\mathrm{H}_{2}$ & 11.0 & 6.0 \\
\hline $\mathrm{CO}$ & 24.0 & 27.0 \\
\hline $\mathrm{CH}_{4}$ & 2.0 & 9.0 \\
\hline $\mathrm{N}_{2}$ & 46.0 & 41.0 \\
\hline $\mathrm{O}_{2}$ & 4.0 & 4.0 \\
\hline $\mathrm{CO}_{2}$ & 9.0 & 9.0 \\
\hline $\mathrm{H}_{2} \mathrm{O}$ & 4.0 & 4.0 \\
\hline
\end{tabular}

During the simulations, the combustion of hard coal was assumed to be complete. The mass fraction of the main components of coal is equal as follows: $c=0.650 ; h=0.048 ; s=0.004 ; o=0.128 ; n=0.017$; $w=0.100$. The flue gases from the combustion were mixed with the reburning fuel.

The calculations were modelled using GRI-Mech 2.11 mechanism. This version is relevant to analysing reburning process. The flue gases were mixed with the reburning fuel. The molar flow rates ratio of the reburning fuel is assumed to be $5 \%, 10 \%$ and $15 \%$ of the whole exhaust. The simulations were conducted for a constant pressure equal to $1 \mathrm{~atm}$. for temperatures range from $600 \mathrm{~K}$ to $1400 \mathrm{~K}$ and typical residence time $0.0-0.4 \mathrm{~s}$. It was assumed that a flue gase which enters into the reburning zone contains $300 \mathrm{ppm}$ of $\mathrm{NO}$ and that during combustion only $\mathrm{NO}$ is formed without other $\mathrm{NO}_{\mathrm{x}}$.

\section{RESULTS}

The obtained results show how a relative amount of NO depends on the air excess ratio, temperature of the reburning process, the molar flow rates ratio of reburning fuel and the residence time in reburning zone.

\subsection{Influence of the molar flow rates of reburning fuel}

Figure 3 (a-c) shows the dependence of a relative amount of NO as functions of air excess ratio for the gas from sewage sludge gasification no 1 (ss1) for different rates of molar ratio of the reburning fuel. While analysing Figure 3 it can be said that the most intensive reduction is observed for the value of air excess ratio equal to 1.1 and the temperature equal to $1200 \mathrm{~K}$. However, it can be noticed that an increment of the molar ratio of reburning fuel $(10 \%)$ leads to an enlargement of the temperature range in which NO reduction is the most intensive. For example, for the case presented in Fig. 1b, an equally high NO reduction is obtained for the range of the reburning zone temperature equal to $1100-1400 \mathrm{~K}$. Moreover, it seems that a further increment of the molar flow rate $(15 \%)$ of reburning fuel leads to a further enlargement of the interval of the reburning zone temperature in which NO reduction is the 
most effective - in Fig. $\mathrm{c}$ the efficiency of NO reduction even at $900 \mathrm{~K}$ is quite high and equal to $35 \%$. The best efficiency (almost 90\%) was obtained at the molar rate of the reburning fuel equal to $15 \%$. However, it is worth emphasising that such a high value of NO reduction in a real system would be considered as an excellent value.

a)

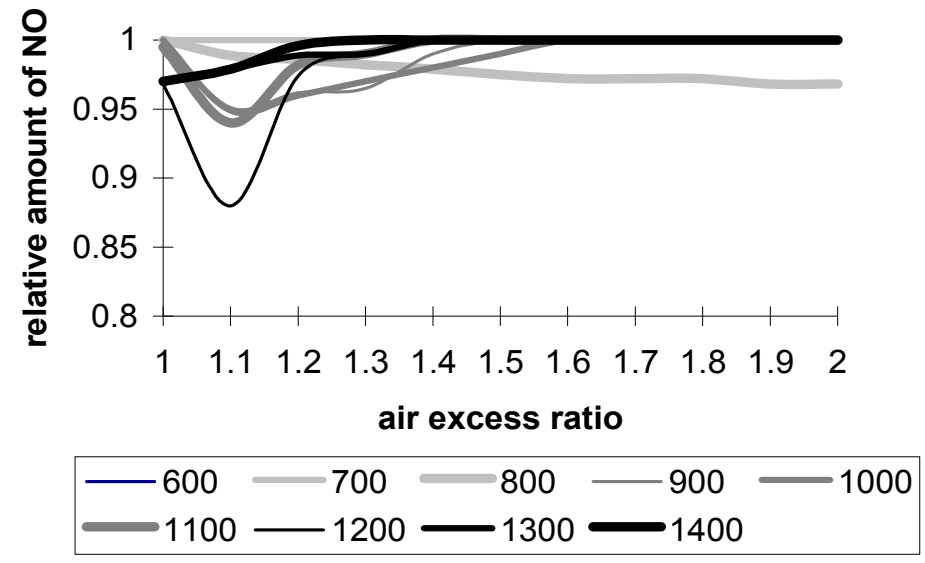

b)

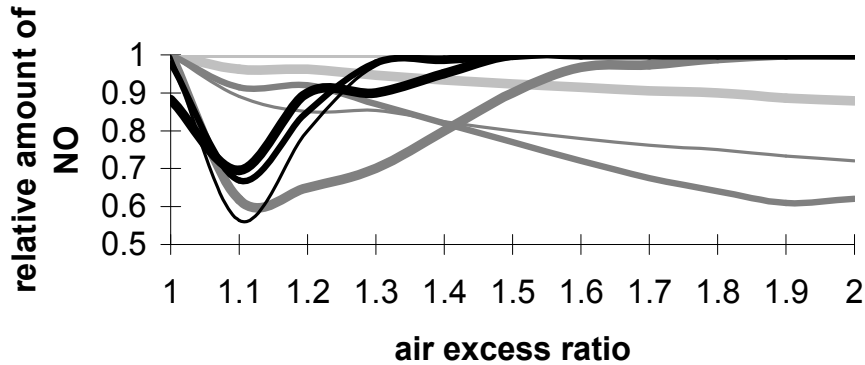

\begin{tabular}{|ccccc}
\hline 600 & 700 & 800 & -900 & -1000 \\
1100 & -1200 & -1300 & 1400
\end{tabular}

c)

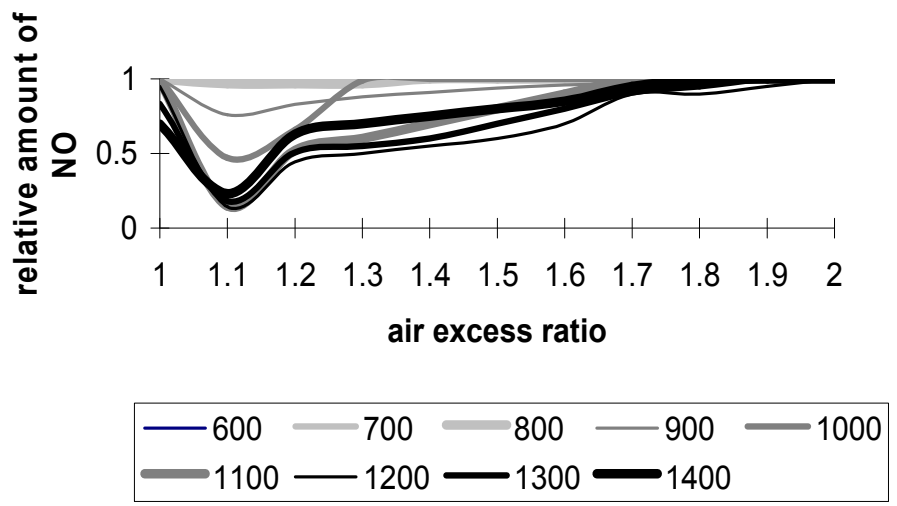

Fig. 3. Relative NO concentration as a function of air excess ratio; a) ss $1 ; 5 \% ; \tau=0.4 \mathrm{~s} ; \mathrm{b}) \mathrm{ss} 1 ; 10 \%, \tau=0.4 \mathrm{~s}$; c) $\mathrm{ss} 1 ; 15 \%, \tau=0.4 \mathrm{~s}$

\subsection{Influence of the air excess ratio}

Figure 4 shows dependence of efficiency of NO reduction as a function of air excess ratio for temperature in the reburning zone equal to $1200 \mathrm{~K}$ and the residence time in the reburning zone equal to $0.4 \mathrm{~s}$ (for ss 1 ). While analysing this figure, it can be seen that at the air excess ratio equal to 1.0 reburning fuel has no influence on NO reduction. 


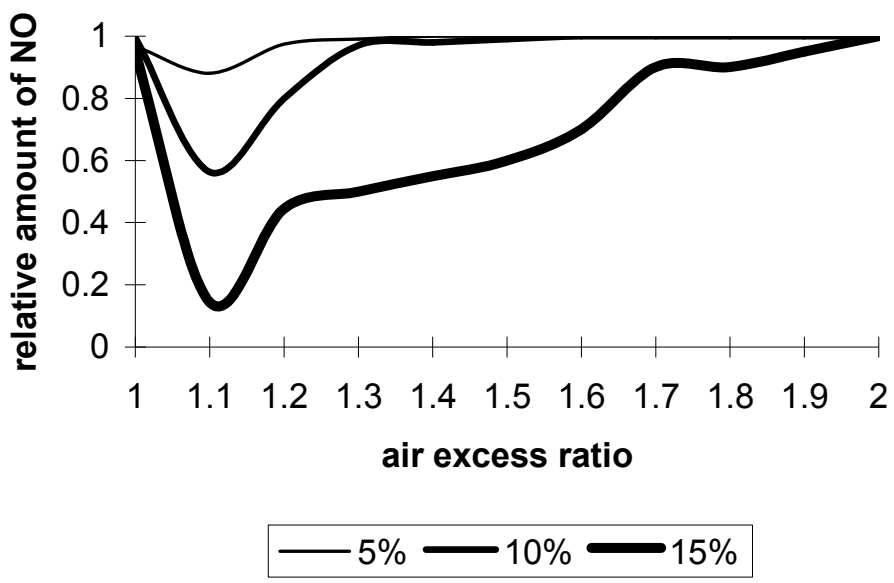

Fig. 4. Relative amount of NO as a function of air excess ratio for different values of molar ratio of reburning fuel (ss $1 ; T=1200 \mathrm{~K} ; \tau=0.4 \mathrm{~s})$

It can be observed for each presented curve, that a relative amount of NO decreases at the beginning with the growth of the air excess ratio. As can be observed in this Figure, there is a value of air excess ratio, in which the efficiency of $\mathrm{NO}$ reduction reaches its maximum (simultaneously minimum values of the amount of NO). Above the value of air excess ratio in which NO reduction is the highest, this parameter decreases (simultaneously the relative amount of NO increases). Generally it can be concluded that with increasing the molar rate of reburning fuel ratio the efficiency of NO reduction increases.

\subsection{Influence of the reburning temperature}

In Figure 5 the relative amount of $\mathrm{NO}$ as a function of temperature in the reburning zone is shown. NO reduction efficiency of sewage sludge gasification gas is strongly dependent on temperature. For example, at temperatures between $600-800 \mathrm{~K}$ sewage sludge derived syngas does not affect NO concentration. At higher temperatures, reburning efficiency of the analysed reburning fuel increases. The strongest NO reduction begins at temperatures higher than $1000 \mathrm{~K}$. The best temperature for reburning is equal to $1200 \mathrm{~K}$. It can be concluded that with increasing the rate of molar ratio of the reburning fuel, the optimum temperature for NO reduction is lower.

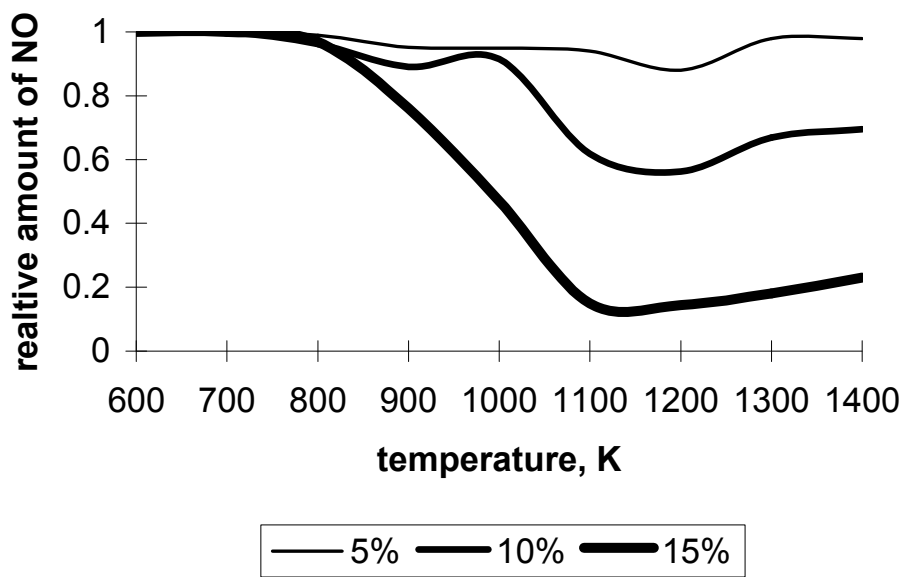

Fig. 5. Relative amount of $\mathrm{NO}$ as a function of temperature in the reburning zone for different values of molar ratio of reburning fuel $(\mathrm{ss} 1 ; \lambda=1.1 ; \tau=0.4 \mathrm{~s})$ 


\subsection{Influence of the residence time}

Figure 6 shows how relative NO concentration depends on the residence time.

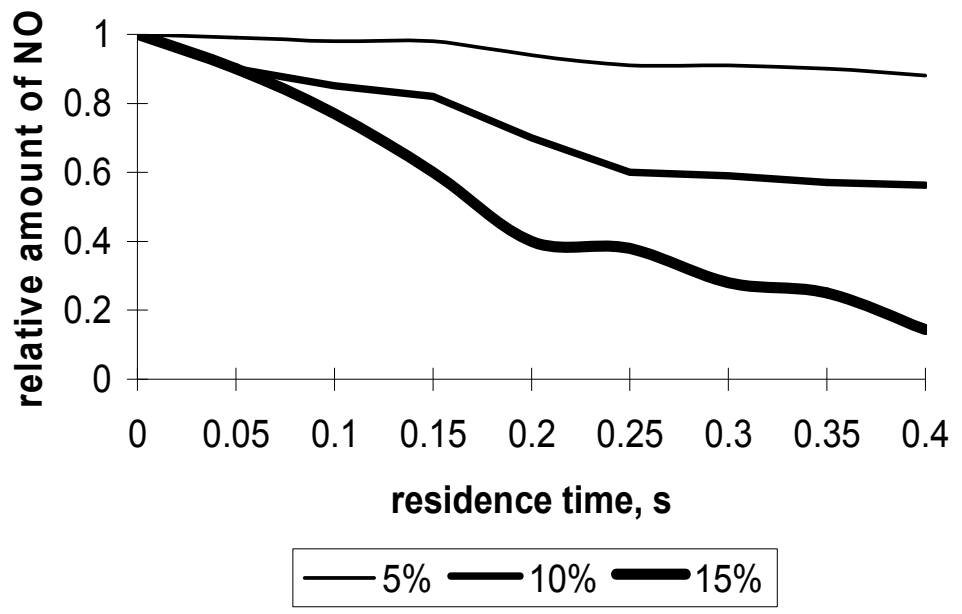

Fig. 6. Relative NO concentration in dependence on residence time $(\mathrm{ss} 1, T=1200 \mathrm{~K} ; \lambda=1.1)$

The most intensive reduction of NO for the range of residence time equal to $0.05-0.20 \mathrm{~s}$ is observed. Generally it can be said, that above this time interval the concentration remains constant. However, an increment of the rate of the molar ratio of the reburning fuel leads to a much longer time in which $\mathrm{NO}$ reduction is effective. Finally, the highest NO reduction for syngas from sewage sludge gasification gas occurs at $0.4 \mathrm{~s}$ for the molar ratio of the reburning fuel equal to $15 \%$.

\subsection{Influence of the type of sewage sludge gasification gas}

Figure 7 (a-c) shows a comparison of the results for two different types of sewage sludge gasification gas (ss1 and ss2). This figure presents dependence of a relative amount of $\mathrm{NO}$ as a function of air excess ratio, temperature in the reburning zone and the residence time. While analysing this figure we can see that the efficiency of NO reduction for using ss2 as the reburning fuel is significantly higher in comparison with ss1. The difference is particularly substantial for the molar fraction of the reburning fuel equal to 5 and $10 \%$. However, it can be observed that at the molar fraction of the reburning fuel equal to $15 \%$ the type of sewage sludge derived syngas has no influence on the efficiency of NO reduction (in that case both syngases used in the process are characterised by more or less the same value of NO reduction). The gas from the sewage sludge gasification process denoted as ss 2 is characterised by a lower molar concentration of nitrogen and higher values of carbon monoxide and methane. It is also very characteristic that despite the lack of differences in the values of achieved NO reduction efficiency for the molar fraction of the reburning fuel of $15 \%$, gas ss 2 is characterised by a much wider range of the air excess ratio in which NO reduction is the highest. It is caused by the mass composition of sewage sludge (and the molar composition of syngas, simultaneously - a low level of nitrogen in sewage sludge and in the syngas). It should be also mentioned that ss2 reaches the highest NO reduction efficiency in higher temperatures in comparison to ss 1 . It is caused by a higher methane concentration in ss 2 . Methane needs more time and higher temperatures to decrease NO concentration. 
a)
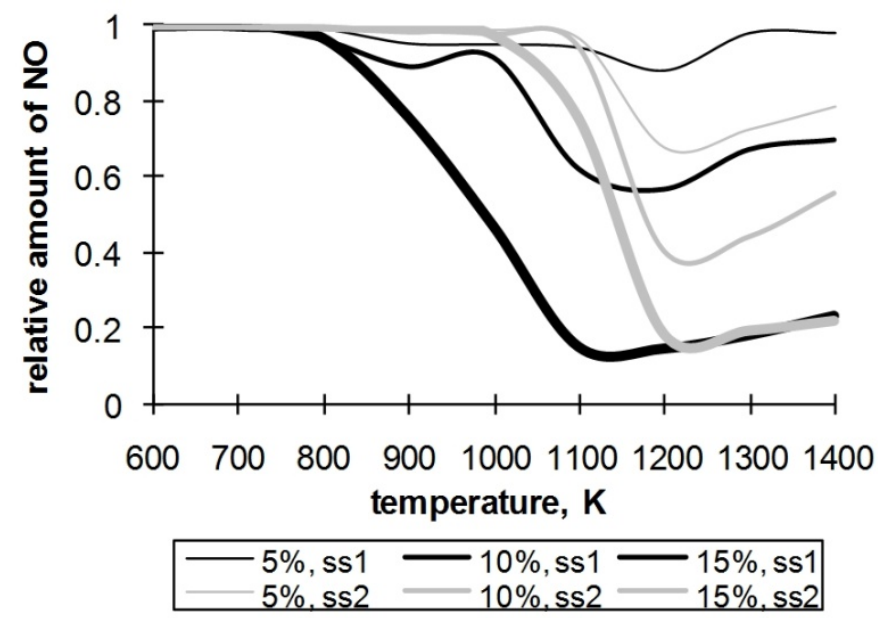

b)

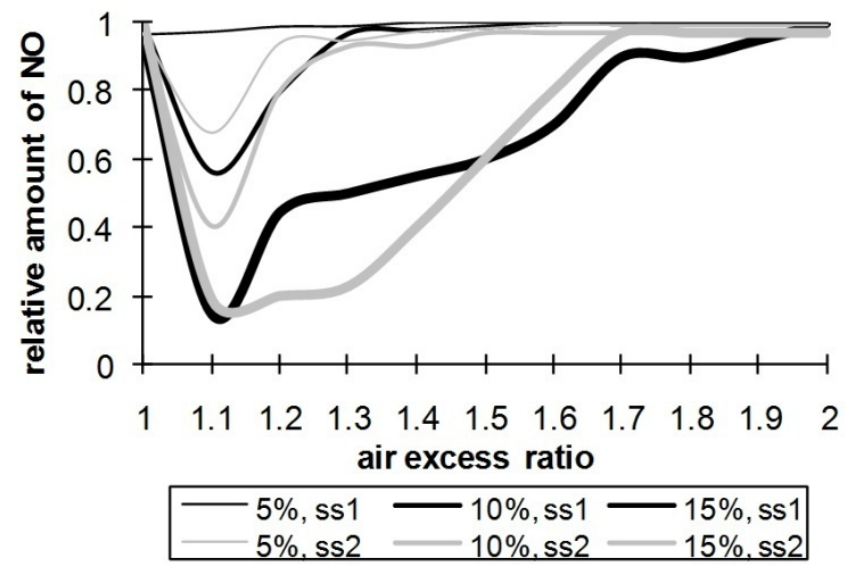

c)

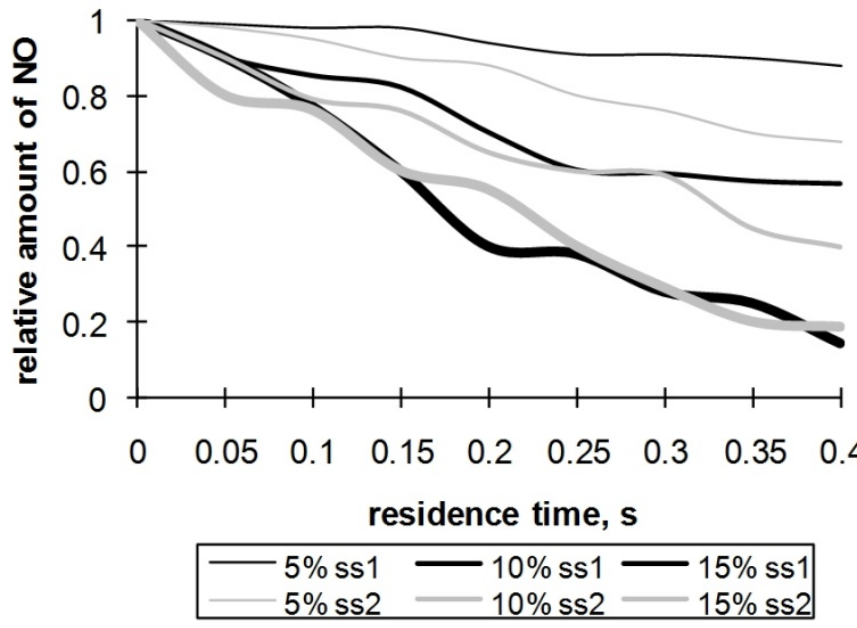

Fig. 7. A comparison of results for two types of sewage sludge gasification gas;

a) function of air excess ratio; b) function of the temperature; c) function of the residence time

\section{CONCLUSIONS}

- Alternative methods for thermal utilisation of sewage sludge (e.g. gasification process) are an important element in the wider problem of sludge disposal. There are many technologies that use gasification or pyrolysis (or a combination of these two). Their undoubted advantage, in addition to the disposal of sludge, is that it becomes possible to obtain a product that can be effectively used 
for the generation of energy. Polish conditions also appear to present a good opportunity to apply this group of waste-disposal technologies.

- Reburning is considered to be one of the most promising and cost-effective NO reduction strategies for coal combustion systems.

- Gas from sewage sludge gasification is a good example of reburning fuel.

- A calculation shows that gas from sewage sludge gasification gives efficiency of up to $90 \%$.

- The optimum value of temperature reburning for the gas from sewage sludge gasification is equal to $1200 \mathrm{~K}$.

- The type of sewage sludge has no marked influence on NO reduction

\section{REFERENCES}

Adams B.R., Harding N.S., 1998. Reburning using biomass for $\mathrm{NO}_{\mathrm{x}}$ control. Fuel Process. Technol., 54, $249-263$. DOI: $10.1016 / \mathrm{S} 0378-3820(97) 00072-6$.

Bilbao R., Alzueta M.U., Millera A., Cantin V., 1995. Experimental study and modeling of the burnout zone in the natural gas reburning process. Chem. Eng. Sci., 50, 2579-2587. DOI: 10.1016/0009-2509(95)00119-P.

Cariln N.T., Annamalai K., Harman W.L., Sweeten J.M., 2009. The economics of reburning with cattle manurebased biomass in existing coal-fired power plants for $\mathrm{NO}_{\mathrm{x}}$ and $\mathrm{CO}_{2}$ emissions control. Biomass Bioenerg., 33, 1139-1157. DOI: 10.1016/j.biombioe.2009.04.007.

Dagaut P., Lecomte F., Chevallier S., Cathonnet M., 1998. Experimental and detailed kinetic modeling of nitric oxide reduction by a natural gas blend in simulated reburning conditions. Combust. Sci. and Technol., 139, 329363. DOI: 10.1080/00102209808952093.

Dąbrowski J., Piecuch T., 2011. Mathematical description of combustion process of selected groups of waste. Rocznik Ochr. Środ., 13, 253-268.

Folsom B.A., Sommer T.M., Payne R., 1991. Demonstration of combined $\mathrm{NO}_{\mathrm{x}}$ and $\mathrm{SO}_{2}$ emission control technologies involving gas reburning. AFRE-JFRC International Conference on Environmental Control of Combustion Processes, Honolulu.

Folsom B.A., 1997. Advanced gas reburning demonstration and commercial gas reburning system upgrade. Fuel Energy Abstracts, 4, 227. DOI: 10.1016/S0140-6701(97)84634-6.

Frassoldati A., Faravelli T., Ranzi E., 2007. The ignition, combustion and flame structure of carbon monoxide/hydrogen mixtures. Note 1: Detailed kinetic modeling of syngas combustion also in presence of nitrogen compounds. Int. J Hydrogen Energy, 32, 3471-3485. DOI: 10.1016/j.ijhydene.2007.01.011.

Galborg P., Alzueta M.U., Dam-Johansen K., Miller J.A., 1998. Kinetic modeling of hydrocarbon/nitric oxides interactions in a flow reactor. Combust. Flame, 115, 1-27. DOI: 10.1016/S0010-2180(97)00359-3.

Glarborg P., Lilleheie N.I., Byggstoyl S., Magnussen F., Klipinen P., Hupa M., 1992. A reduced mechanism for nitrogen chemistry in methane combustion. Proc. Combustion Inst., 24, 889-895.

Hardy T., 2003. Efficiency of $\mathrm{NO}_{\mathrm{x}}$ reduction from pulverized boilers using reburning. Archiwum Spalania, 2-4, 33-49 (In Polish).

Hewson J.C., Bollig M., 1992. Reduced mechanism for $\mathrm{NO}_{\mathrm{x}}$ emissions from hydrocarbon diffusion flames. Proc. Combustion Inst., 24, 2171-2179.

Klipinen P., Galborg P.P., Hupa M., 1992. Reburning chemistry: a kinetic modeling study. Ind. Eng. Chem. Res., 31, 1478-1490. DOI: 10.1021/ie00006a009.

Lanigan E.P., Golland E.S., Rhine J.M., 1991. The demonstration of gas reburning at Longannet: leading the world in low- $\mathrm{NO}_{\mathrm{x}}$ technology. International Gas Reburn Technology Workshop, Sweden, 121-138.

Maly P.M., Zamansky V.M., Ho L., Payne R., 1999. Alternative fuel reburning. Fuel, 78, 327-334. DOI: 10.1016/S0016-2361(98)00161-6.

Miller J.A., Bowman C.T., 1989. Mechanism and modeling of nitrogen chemistry in combustion. Prog. Energy Combust. Sci., 15, 287-338. DOI: 10.1016/0360-1285(89)90017-8.

Norman F., Andersson K., Leckner B., Johnsson F., 2009. Emission control of nitrogen in the oxy-fuel process. Prog. Energy Combust. Sci., 35, 385-397. DOI: 10.1016/j.pecs.2009.04.002. 
Piecuch T., Dąbrowski J., Dąbrowski T., 2009. A laboratory investigations on possibility of thermal utilization of post-production Waste polyester. Rocznik Ochr. Środ., 11, 87-101.

Shen B., Yao Q., Xu X., 2004. Kinetic model for natural gas reburning. Fuel Process. Technol., 85, 1301-1315. DOI: 10.1016/j.fuproc.2003.09.005.

Smith G.P., Golden D.P., Frenklach M., Moriarty N.W., Eiteneer B., Goldenberg M., Bowman C.T., Hanson R.K., Song S., Gardiner W.C., Lissianski Jr. V.V., Qin Z., Gri-Mech 2.11, www.me.berkeley.edu/gri_mech/

Smoot L.D., 1998. International research centers' activities in coal combustion. Prog. Energy Combust. Sci., 24, 409-501. DOI: 10.1016/S0360-1285(97)00032-4.

Smoot L.D., Hill S.C., Xu H., 1998. $\mathrm{NO}_{\mathrm{x}}$ control through reburning. Prog. Energy Combust. Sci., 24, $385-408$. DOI: $10.1016 / \mathrm{S} 0360-1285(97) 00022-1$.

Szkarowski A., 2001. Technology of $\mathrm{NO}_{\mathrm{x}}$ emission reduction using method of flame dosed direction ballasting. Rocznik Ochr. Środ., 3, 54-73.

Szkarowski A. 2002. Principles of calculation at suppression of $\mathrm{NO}_{\mathrm{x}}$ formation by a method of the dosed directed injection of a water ballast. Rocznik Ochr. Środ., 4, 366-378.

Takahashi Y., Sakai M., Kunimoto T., Ohme S., Haneda H., Kawamura T., Kaneko S., 1983. Proc. the 1982 Joint Symposium on Stationary $\mathrm{NO}_{x}$ Control, EPRI Report No. CS-3182.

Wendt J.O.L., Sternling C.V., Matovich M.A., 1972. Reduction of sulfur trioxide and nitrogen oxides by secondary fuel injection, Fourteenth Symposium on Combustion, 881, The Combustion Institute, Pittsburgh, PA.

Werle S., 2012. A reburnig process using sewage sludge-derived syngas. Chem. Pap., 2, 99-107. DOI: 10.2478/s11696-011-0098-y.

Werle S., 2011. Modeling of the reburnig process using sewage sludge-derived syngas. Waste Manage. DOI: 10.1016/j.wasman.2011.10.013.

Werle S., Wilk R.K, 2010. A review of methods for the thermal utilization of sewage sludge: The Polish perspective. Renew. Energy, 35, 1914-1919. DOI: 10.1016/j.renene.2010.01.019.

Received 08 April 2011

Received in revised form 16 December 2011

Accepted 27 December 2011 